\title{
Re-thinking the feminist agenda in selected female authored Zimbabwean literature.
}

\author{
Salachi Naidoo \\ Great Zimbabwe University, Zimbabwe \\ snaidoo@gzu.ac.zw
}

\begin{abstract}
This article investigates the feminist agenda in female authored Zimbabwean literature, with emphasis on the novel. It focuses largely on Virginia Phiri's Destiny and Highway Queen as well as Violet Masilo's The African Tea Cosy. The paper argues that Zimbabwean female authorship is flavoured with precepts of African feminism(s) in its representations of African women's agency in gender adversities. Framed within African feminism, women's agency derives from and gives meaning to an inescapable African-ness that needs to be accepted in the fight for emancipation. In light of this, the study analyses Zimbabwean women writers' literary contributions to discourses on gender based violence and it explores how female characters have embraced the concept of agency to recreate their identities and to introduce a new gender ethos in the context of lives that are often shaped by severe restrictions and oppression. Although largely women focused, the African feminist text is concerned about the survival of both men and women.
\end{abstract}

Key words: agency, African feminism, womanhood, feminist, gender violence, oppression, survival

\section{Introduction}

Feminism as a discipline has evolved quite considerably from its advent during the $19^{\text {th }}$ and early $20^{\text {th }}$ centuries. In the present day, it makes more sense to talk about feminisms in the plural rather than feminism in the singular. The focus of feminism, despite the diversity of its articulations in different geo-political and social spaces has remained the advocacy for women's rights. The understanding and practice of feminism has mutated to different societies, given the politics of place and space. These differences have led to the mutations of feminism. Although cognizant of all these varieties, this paper explores African feminism within the context of Zimbabwe and, in particular, what the researcher perceives to be the Zimbabwean feminist agenda as driven by female writers of literature in Zimbabwe across the intersections of race, ethnicity and class. 
African feminism has been described differently by different scholars. A central feature of African feminism is captured by Davies and Adam Graves (1986), in their introduction to Ngambika: Studies of Women in African Literature as they observe that African feminism is accommodative of African men and tries to make them aware of women's extra suffering beyond being black. As such, African feminism is firmly grounded in African women's resistance to Western feminisms and is "distinctly heterosexual, prenatal and concerned with many bread, butter, culture and power issues" (Mikell, 1997 p.4). In an interview with Eline Salo, Amina Mama asserts that African feminism "signals a refusal of oppression, and a commitment to struggling for women's liberation from all forms of oppression - internal, external, psychological and emotional, socio-economic, political and philosophical" (Salo, 2001 p.59). Given the conscious effort by African women to dissociate themselves from western feminisms, The African Feminist Forum (2015), in the preamble to the Charter of feminist principles for African feminists, reminds African women of the role and nature of an African feminist and advises them not to focus on the politics of naming the practice of feminism in Africa. The African Feminist Forum (cited in Weiss 2018 p450) outlines the identity of an African Feminist thus:

We define and name ourselves publicly as feminists because we celebrate feminist identities and politics. We recognise that the work of fighting for women's rights is deeply political and the process of naming is political too. Choosing to name ourselves feminists places our in a clear ideological position. By naming ourselves feminists WE politicise the struggle for women's rights. Further, we question the legitimacy of the structures that keep women subjugated from which we develop tools for transformatory analysis and action. There are multiple and varied identities to African feminists. African women live here in Africa and even when they live elsewhere, focus is on the lives of African women on the continent. Feminist identity is not qualified with "ifs", "buts" or "howevers"; "We are Feminists. Full stop."

This valuation of the feminist in Africa lays bare the mission of African feminism, which is to fight against the oppression of women. More recently, Gaidzanwa (2011) adds to African feminist debates and concludes that African feminism reacts to the "devaluation and misrepresentations of various African cultures and traditions by colonialists" (Gaidzanwa, 2011 p.6). African feminism's focus on African cultures and misrepresentations marks a departure from western feminisms for which some of these factors are no concern.

\section{Zimbabwe's early feminist literary writing}

This paper identifies the early novels of Tsitsi Dangarembga and Yvonne Vera as ground breaking novels of Zimbabwe's feminist literary writing in English. The focus 
of these two writers, which provides the foundation for later feminist writing in Zimbabwe is on giving voice to women as well as the gendering and positioning of women in national historical narratives. A major development in their feminist articulations, which departs from elitist mainstream western feminism, as it is known, is the identification of varied and often intimate spaces within which gender oppression takes place as well as women's agency in averting oppression. Agency, in this paper, is to be understood in the context of "what a person is free to do and achieve in pursuit of whatever goals or values he or she regards as important" (Sen 1985 p.203). With developments on the literary scene, female Zimbabwean novelists have moved further away from mainstream western feminism and have become more conscious of intricacies of African womanhood that women in the western world would not easily identify with. Although cognisant of numerous feminist writers that have enriched Zimbabwe's literary arena, this paper focuses mainly on two of the new female writers, in terms of their entry into the literary canon; Virginia Phiri and Violet Masilo. The focus is with particular interest on their contributions to feminist Zimbabwean literary writing on the subject of gender violence.

The early novels by both Vera (Why Don't You Carve Other Animals (1992), Nehanda (1993), Without a Name (1994), Under The Tongue (1996), and The Stone Virgins (2002) and Dangarembga Nervous Conditions (1988) although flavoured with a feminist agency to (re)place women in national narratives were antagonistic towards men in general. It is for such antagonism that researchers like Furusa (2006, p.18) would argue that "relationships between Zimbabwean women and men paint a picture of a culture that unleashes a large-scale, barbaric, and indiscriminate abuse of women."

With the advent of newer authors and perhaps a shift in political and literary focus, the presentation of men has become more accommodative and more reflective of African feminist thought. Davies and Greaves (1986) argue that it is aimed at achieving harmony between African men and women by helping men to appreciate women's suffering and to work with African women to end oppression. The new feminist agenda of most of the newer (post 2000) female authored Zimbabwean literature is accommodative of men and seeks to make them aware of women's suffering and to get them to fight alongside their women. This is not to suggest that all female authored Zimbabwean literature published post 2000 is feminist or that it homogeneously serves the same purpose. However, the main concerns of the feminist agenda in literature that does serve this purpose in the post 2000 era, centre on freedom of expression, gender politics in publishing, representation of women and girls in literature, continued suffering in the post colony, sexuality, education, marriage and oppressive cultures and traditions. 


\section{Agency and survival in adversity in contemporary feminist writing in Zimbabwe}

Literary writing in Zimbabwe, however, vivid and compelling, has not been without constraints, given the conservatism that characterizes Zimbabwean and African societies. Vera (1999 p.1) in the preface to Opening Spaces argues that, "a woman writer must have an imagination that is plain stubborn, that can invent new gods and banish ineffectual ones." She adds that "writing offers a moment of intervention" (Vera, 1999 p.3), for women to speak out and be heard. A "...woman writer also needs a thick skin, for she does not know when and how it may crack" (Gasa, 2007 p.ix). Zimbabwe's female authorship has, to a large extent, heeded this call and writers are, in a subtle way, tackling social ills of the so called taboo subjects in their pursuit of a Zimbabwean feminist agenda.

Virginia Phiri stormed the literary canon with two novels; Destiny (2006) and Highway Queen (2010). Destiny is a novel about a physically challenged 'girl' Gloria, a 'hermaphrodite'- one born with both male and female sex organs. Gloria's tragedy is that of not being in control of her own life and having decisions made for her by other people, especially men. The representation of Gloria as a woman who at first chooses not to have her condition fixed, confirms the view that African women, although aware of the violence and oppression around them; "react with fear, depending on complexes and attitudes to please and cajole where more self-assertive actions are needed" (Ogundipe-Leslie, 1994 p.10). The representation also portrays her as a passive victim of her own suffering. The plot, however, progresses to a climax when Gloria is assisted by her brothers and members of the community to escape an arranged marriage that would have led to so much pain and suffering, given her hermaphroditsm. The way in which the community pretends to play along with the plans for the marriage only to break off the arrangements and help Gloria escape, resonates with Scott's (1990 p.42) concept of hidden transcripts, in which "dominant elites attempt to portray social action in the public transcript as, metaphorically, a parade, thus denying, by omission, the possibility of autonomous social action by subordinates. Gloria's escape can be read as an autonomous social action by a subordinate.

Virginia Phiri, in her second novel, Highway Queen (2010), explores various forms of oppression and violence including rape, forced and child marriages. The novel further exposes the complicity of women in the oppression of other women and girls, especially through the family system that is meant to protect women. Highway Queen, compels the reader to re-think sex and sexuality in the post colony. This is a novel about prostitutes and the profession of prostitution. The prostitutes she presents are of various ages and backgrounds. The novel makes an attempt at exposing the humanity of the prostitute. The prostitutes in the novel are mostly wives who, having 
tried all else, realise that sex is the only valuable commodity that they have at their disposal and they exploit it to make a living. The novelist ventures into the uncomfortable space of sex and sexuality and exposes a practice of prostitution amongst wives, which although common, conservative African societies would rather not talk about. In venturing into the space, Phiri (2010) uses writing as "a moment of intervention" (Vera, 1999 p.3). She writes the adversities that prostitutes encounter and describes the varied backgrounds of prostitutes thereby compelling the reader to reconsider prostitution as a practice.

Using an African feminist reading of Highway Queen, despite its attempt at vindicating prostitutes, the novel attempts to uphold the sanctity of the marriage institution. This is achieved mainly through the protagonist, Sophie, a married prostitute, who remains conscious of her African-ness throughout her sex-selling. Sophie remembers to always wear her headscarf. This is a symbol of a respectable woman in her community. She consoles herself that prostitution is a necessary evil for the survival of her family. Highway Queen, through exposing wives, mothers, and daughters being forced by circumstances into prostitution, also exposes the precariousness of the lives of ordinary African women, subdued in socio-economic suppression. In showing female characters surviving through prostitution, the novel shows that "[b]odies and sexuality are not only sites of other's inscribed meaning, but also sources of African women's agency" (Lewis, 2011 p.207).

The prostitutes in the novel are agents of survival. The agency of the women in using their bodies for survival compels one to appreciate that prostitution provides a means of livelihood to these women and their families. The agency of women in prostituting themselves also resonates with Hunter's (2002) view that women approach trade relations in order to access power and resources in ways that can either challenge or reproduce patriarchal structures. This is to suggest that women do not necessarily enter into prostitution as mere victims but rather as co-conspirators. In Highway Queen, the clients (men) who buy sex from prostitutes are largely portrayed as loyal business associates who honour the deal and pay for services provided. Only two of the male characters, Samson and Peter, are portrayed as dishonest and abusive.

Violet Masilo's African Tea Cosy (2010), tells the story of four women- (Catherine, Heather, Anna and Joy) living in the city and how they manoeuvre life, map out survival strategies and live life as best they can. Masilo's (2010) female characters, although partaking in the trading of sex, are not directly labelled prostitutes. These women come from diverse backgrounds and have been hurt at some point in their lives especially by men -fathers, uncles, lovers, but they do not give up on love. There is an anti-climax in the novel when in a fit of desperation for survival, the women murder an abusive male character, decide to go on holiday and feed the body to crocodiles. The presentation poses a challenge for African feminist thought in 
relation to the harmonising of the genders if men should be killed to give women space. However, the women have a shocking agency for survival and a unity that calls to mind the notion of sisterhood as proposed by Mohanty (1995). For Mohanty (1995 p.77), the unity of women is best understood "not as given... [it] has to be worked for, struggled toward - in history." In her view, sisterhood is not biological or universal; it is acquired through historical experience and relatedness. It is thus the experience of poverty and oppression that unites prostitutes and defines them as sisters.

\section{Conclusion}

Zimbabwe's literary feminist agenda has developed over the last couple of decades that it has been in existence. The late entry of women onto Zimbabwe's literary scene has not derailed feminist agency in Zimbabwe's feminist authorship. Zimbabwe's feminist agenda, although owing its origins to western feminism, is mostly aligned to African feminisms. Although the initial feminist agenda as shown in the early novels of Zimbabwe's early feminist writing by Yvonne Vera and Tsitsi Dangarembga was to (re)place women in national narratives, their representations out rightly demonised African men without offering any hope for harmonisation of the genders.

However, this agenda has largely transformed, with focus now being on the unity of African men and women in the fight against domination, and in particular, against gender violence. These writers present women in precarious situations who are aware of the opacity of their options but who choose to place survival at the centre of their agency. The study recommends that novelists continue to break barriers and write on behalf of other women. By speaking the unspeakable, female novelists have the potential to influence debates and discussions that can aid Zimbabwe's feminist agenda. They can influence government, men and women in positions of authority to formulate effective policies and laws to combat gender violence. More and newer novels that narrate contemporary society should be included in schools, colleges and university curricula for critical analysis and appreciation of the feminist agenda. It also recommends that more women be encouraged to write novels so as to have diverse voices in the literary arena.

\section{REFERENCES}

Dangarembga, T. 1988. Nervous Conditions. Seattle: Seal.

Davies, C. B. and Graves, A. A. eds. 1986. Ngambika: Studies of Women in African Literature. New Jersey: Africa World Press Inc. 
Re-thinking the feminist agenda in selected female authored Zimbabwe Literature.

Furusa, M. 2006. The Muse of History and Politics of Gender Representation in Zimbabwean Women's Literature, in Z. Mguni, M. Furusa and R. Magosvongwe, (Eds.). African Womanhood in Zimbabwean Literature: New Critical Perspectives on Women's Literature in African Languages. Harare: College Press, pp.1-23.

Gaidzanwa, R.B. 2011. African feminism. BUWA-A Journal of African Women's Experiences. Available online http://www.osisa.org/buwa/regional/africanfeminism (accessed 04/04/2015.)

Gasa, N., 2007. Women in South African History: They remove boulders and cross rivers. Johannesburg: HSRC Press.

Hunter, M. 2002. The materiality of everyday sex: thinking beyond 'prostitution'. African Studies. 61(1):99-120.

Lewis, D. 2011. Representing African sexualities. In African Sexualities: a reader. S. Tamale. Ed. Cape Town: Pambazuka Press.199-216.

Masilo, V. 2010. The African Tea Cosy. Harare: Zimbabwe Women Writers.

Mikell, G. ed. 1997. African Feminism: the politics of survival in Sub-Saharan Africa. Philadelphia: Philadelphia Press.

Mohanty, C.T. 1995. Feminist encounters: locating the politics of experience. In Social postmodernism: beyond identity politics. L. Nicholson \& S. Seidman. Eds. Cambridge: Cambridge University Press, pp.68-86.

Phiri, V. 2002. Destiny. Harare: Coral Services.

Phiri, V. 2010. Highway Queen. Harare: Coral Services.

Salo, E. 2001. Elaine Salo Speaks to Amina Mama Talking About Feminism in Africa'. Agenda, 50: 58-63.

Scott, J.C. 1990. Domination and the art of resistance: hidden transcripts. New Haven and London: Yale University Press.

Sen, A. K. 1985. Well-being, agency and freedom. The Journal of Philosophy LXXXII: 169-221.

Vera, V. 1992. Why Don't you Carve Other Animals. Michigan: Tsar Publications. 1993. Nehanda. Harare: Baobab Books. 
Salachi Naidoo

1994. Without a Name: A novel. Michigan: Tsar Publication.

1996. Under The Tongue. Harare: Baobab Books.

1999. Opening spaces: An anthology of contemporary African women's writing.

London: Heinemann.

2002. The stone virgins: a novel. London: Macmillan.

Weiss, B. A. 2018. Feminist manifestos: A Global Documentary Reader. New York: New York: University Press 